\title{
What's new in the management of adult bronchiectasis?
}

\section{[version 1; peer review: 2 approved]}

\author{
Usma Koser (iD, Adam Hill
}

Department of Respiratory Medicine, Royal Infirmary and University of Edinburgh, 51 Little France Crescent, Old Dalkeith Road, Edinburgh, EH16 4SA, UK

V1 First published: 20 Apr 2017, 6(F1000 Faculty Rev):527
https://doi.org/10.12688/f1000research.10613.1

Latest published: 20 Apr 2017, 6(F1000 Faculty Rev):527

https://doi.org/10.12688/f1000research.10613.1

\section{Abstract}

Bronchiectasis is a heterogeneous, chronic condition with many aetiologies. It poses a significant burden on patients and healthcare practitioners and services. Clinical exacerbations often result in reduced quality of life, increased rate of lung function decline, increased hospitalisation, and mortality. Recent focus in respiratory research, guidelines, and future management options has improved this clinical field in evidence-based practice, but further work and phase III clinical trials are required. This article aims to summarise and explore advances in management strategies in recent years and highlight areas of research and future focus.

\section{Keywords}

Bronchiectasis, NCFB, Non-Cystic Fibrosis bronchiectasis,

\section{Open Peer Review}

Approval Status

1 2

\section{version 1}

20 Apr 2017

Faculty Reviews are review articles written by the prestigious Members of Faculty Opinions. The articles are commissioned and peer reviewed before publication to ensure that the final, published version is comprehensive and accessible. The reviewers who approved the final version are listed with their names and affiliations.

\section{Miguel Ángel Martinez-García, Hospital}

Universitario y Politécnico La Fe, Valencia,

Valencia, Spain

2. Diana Bilton, Department of Respiratory

Medicine, Royal Brompton Hospital, London,

UK

Michael Loebinger, Royal Brompton \&

Harefield Hospital Foundation Trust and

Imperial College London, London, UK

Any comments on the article can be found at the end of the article. 
Corresponding author: Usma Koser (usma.koser@nhs.net)

Competing interests: The authors declare that they have no competing interests.

Grant information: The author(s) declared that no grants were involved in supporting this work.

Copyright: (c) 2017 Koser U and Hill A. This is an open access article distributed under the terms of the Creative Commons Attribution License, which permits unrestricted use, distribution, and reproduction in any medium, provided the original work is properly cited. Data associated with the article are available under the terms of the Creative Commons Zero "No rights reserved" data waiver (CC0 1.0 Public domain dedication).

How to cite this article: Koser $U$ and Hill A. What's new in the management of adult bronchiectasis? [version 1; peer review: 2 approved] F1000Research 2017, 6(F1000 Faculty Rev):527 https://doi.org/10.12688/f1000research.10613.1

First published: 20 Apr 2017, 6(F1000 Faculty Rev):527 https://doi.org/10.12688/f1000research.10613.1 


\section{Introduction}

Non-cystic fibrosis bronchiectasis (NCFB) is a chronic inflammatory condition resulting from repeated insult and/or obstruction to small and medium-sized bronchi, leading to fixed dilation and architectural distortion ${ }^{1,2}$. The clinical presentation varies from a chronic, productive, daily cough and recurrent infections to haemoptysis, dyspnoea, and respiratory failure ${ }^{2,3}$.

Bronchiectasis has diverse aetiologies, including idiopathic (up to $50 \%$ of cases), post-respiratory tract infection, rare immunodeficiency disorders, genetic abnormalities, autoimmune conditions, chronic inflammation, and mechanical obstruction ${ }^{2,3}$. It is also increasingly being recognised as part of a disease entity coinciding with and complicating other pulmonary conditions such as chronic obstructive pulmonary disease (COPD).

Prevalence rates fluctuate globally, between age groups, and between the sexes and are still largely unknown. However, a recent publication suggests that there is increasing overall incidence and prevalence ${ }^{4}$. In the UK, overall incidence increased from 21 to 35 in women and 18 to 26 in men per 100,000 patient years between 2004 and 2013. The prevalence rates in women increased from 350 to 566 per 100,000 patient years and in men increased from 301 to 485 per 100,000 patient years in the same time $^{4}$. This may be, in part, due to increased diagnosis of the condition and improved computed tomography techniques. The study also illustrated the increased mortality rates in this population group and the need for hospitalisation, further strengthening the case for the increasing impact it has on our healthcare systems ${ }^{4}$.

The mainstay of management is improving symptoms and reducing exacerbations. This article will cover idiopathic and post-infective bronchiectasis in adults and will not include allergic bronchopulmonary aspergillosis (ABPA), cystic fibrosis $(\mathrm{CF})$, immunodeficiency, and non-tuberculous mycobacterium (NTM) disease. It will focus on the therapeutic strategies in bronchiectasis management, particularly highlighting new evidence from between 2013 and 2016.

\section{The patient-led approach}

The first approach to management is to treat the underlying cause if one is identifiable $3,5,6$. British Thoracic Society (BTS) guidelines have a systematic method for screening patients for ABPA, immunodeficiency, $\mathrm{CF}$, and environmental tuberculosis (TB) infection ${ }^{6}$.

The importance of risk stratification has been highlighted in recent years ${ }^{7,8}$. Two main scoring systems have been developed to illustrate severity and mortality - the bronchiectasis severity index (BSI) and FACED ${ }^{9,10}$. Both include $\mathrm{FEV}_{1}$ (forced expiratory volume in 1 second), dyspnoea, Pseudomonas colonisation, and radiological features. They have their limitations, mainly sample size and disparity between mild and moderate phenotypes, but are deemed suitable to predict mortality ${ }^{9,10}$. Additionally, the BSI also includes predictors for hospitalisation and annual mortality risk $^{9}$. These may be useful as adjuncts to decide on clinical management, but further studies are needed to see if such screening systems can be utilised in this way.
The vicious cycle hypothesis was first introduced by Cole and moulds our management interjections ${ }^{11}$. Failure of mucus clearance, persistent infection, and inflammation leading to structural damage are all key aspects. Breaking this cycle by optimising interventions via airway clearance and antibiotic therapy for acute infections has been a backbone of treatment ${ }^{11}$. Broadly categorising therapies into non-pharmacological, pharmacological, and standard and long-term agents, we will explore these aspects and highlight new evidence from the last 3 years.

\section{Standard therapeutic strategies}

Vaccination

There is an established role for the influenza and pneumococcal vaccinations in the management of chronic respiratory and medical conditions. This is based on limited and low-quality evidence $^{12}$. There have been no recent studies specific to bronchiectasis.

Airway clearance techniques and pulmonary rehabilitation Chest physiotherapy forms a core of patient-led management in bronchiectasis irrespective of severity and symptoms. These techniques are patient-centred and variable and aim to aid the removal of secretions from the lung through non-pharmacological methods ${ }^{13}$. Whether these techniques have a clear impact on quality of life or reducing exacerbations has not been adequately proven, and most studies are limited to the $\mathrm{CF}$ patient population $^{13}$. Additionally, the use of multidisciplinary exercise interventions (pulmonary rehabilitation $[\mathrm{PR}]$ ) is seen as an integral part of multimodal management for several chronic diseases ${ }^{14}$. However, much of the data are based on CF or other chronic respiratory conditions. Further randomised controlled trials (RCTs) are required for PR specific to NCFB. Table 1 summarises the most recent studies and their outcomes for both RCTs.

The recent Cochrane review in 2015 included a total of seven studies in children and adults and a total of 105 patients. Overall, they showed within this limited field that airway clearance techniques (ACTs) are safe in adults and improve certain quality of life measures, lung function, and symptoms ${ }^{15}$. Further studies are required to assess the short- and long-term impact on exacerbations and disease progression.

\section{Short-term therapy}

Antimicrobial therapy

Fourteen days of antibiotic therapy is recommended for an acute exacerbation of bronchiectasis. The BTS guidelines identify an exacerbation as deterioration in local symptoms (cough, increased sputum volume or change of viscosity, increased sputum purulence with or without increasing wheeze, dyspnoea, and haemoptysis) and or systemic upset ${ }^{3}$.

Intravenous (IV) antibiotics are required when there has been a failure of oral therapy or there is need for hospital admission or in vitro resistant pathogens that necessitate IV treatment. There were no studies addressing this. More evidence-based practice for choice and duration of antimicrobial therapy is required. The optimal management of exacerbations remains a vast area of untapped research for robust RCTs and future focus. 


\begin{tabular}{|c|c|c|c|c|}
\hline \multirow[t]{4}{*}{$\begin{array}{l}\text { Non-pharmacological } \\
\text { therapy }\end{array}$} & \multirow[t]{4}{*}{ Study } & \multirow[t]{4}{*}{ Study design } & $\begin{array}{l}\text { Results/outcome } \\
\text { Lung function }\end{array}$ & \multirow{4}{*}{$\begin{array}{l}\text { Comments/ } \\
\text { adverse events } \\
\text { (AEs) }\end{array}$} \\
\hline & & & Quality of life & \\
\hline & & & Exercise capacity & \\
\hline & & & Other & \\
\hline \multirow[t]{4}{*}{ ACTs and PR } & \multirow[t]{4}{*}{ Lee et al. ${ }^{38}$} & \multirow{2}{*}{$\begin{array}{l}\text { RCT } \\
\text { PR and ACT versus control }\end{array}$} & No change in FEV1/FVC at study end & \multirow[t]{4}{*}{ No data } \\
\hline & & & $\begin{array}{l}\text { Secondary outcome: improved } \\
\text { scores - LCQ }\end{array}$ & \\
\hline & & \multirow{2}{*}{$\begin{array}{l}43 \text { PR and ACT monitoring } \\
42 \text { unsupervised exercise } \\
\text { training but no ACT monitoring } \\
8 \text { weeks }\end{array}$} & $\begin{array}{l}\text { Primary endpoint: Short-term } \\
\text { improvement in exercise capacity } \\
\text { (shuttle walk - mean difference to } \\
\text { control } 62 \mathrm{~m}, 95 \% \mathrm{Cl} 24 \text { to } 101 \mathrm{~m} \text { ) }\end{array}$ & \\
\hline & & & $\begin{array}{l}\text { No significant difference between } \\
\text { exacerbation rates/duration }\end{array}$ & \\
\hline \multirow[t]{4}{*}{ ACTs } & \multirow{4}{*}{$\begin{array}{l}\text { Nicolini et al. }{ }^{39} \\
\text { HFCWO versus } \\
\text { chest physiotherapy } \\
\text { (CPT) versus medical } \\
\text { therapy only }\end{array}$} & \multirow{4}{*}{$\begin{array}{l}\text { RCT } \\
10 \text { subjects in each group } \\
\text { (treatments up to } 45 \text { minutes for } \\
5 \text { days per week) }\end{array}$} & $\begin{array}{l}\text { Secondary outcome: improved } \\
\text { lung function }(p<0.001 \text { and } \\
p<0.006)\end{array}$ & \multirow[t]{4}{*}{ No AEs } \\
\hline & & & $\begin{array}{l}\text { Primary endpoint: symptom } \\
\text { questionnaires } \\
\text { Improvement of } 2.7 \text { in BCSS in } \\
\text { HFCWO group }(p<0.001)\end{array}$ & \\
\hline & & & & \\
\hline & & & $\begin{array}{l}\text { Increased sputum volume in } \\
\text { the HFCWO and CPT group } \\
\text { compared with control }\end{array}$ & \\
\hline
\end{tabular}

BCSS, breathlessness cough and sputum scale; CI, confidence interval; FEV , forced expiratory volume in 1 second; FVC, forced vital capacity; HFCWO, high-frequency chest wall oscillation; LCQ, Leicester Cough questionnaire; PR, pulmonary rehabilitation.

\section{Eradication therapy}

Patients with known Pseudomonas aeruginosa (PA) have a reported severe phenotype with increased rates of exacerbation and an independent 3 -fold mortality risk $^{16}$. This may be a result of the pathogenicity of the organism and its ability to form biofilms, rendering standard antimicrobial therapies less effective. Therefore, attempted eradication for first isolation is considered reasonable ${ }^{3}$. Further studies are needed to assess 1 ) if eradication is needed and 2) the optimal management regime.

\section{Long-term therapies}

Muco-active therapies

Muco-active therapies can be used for both exacerbations and chronic management. Available as oral, inhaled, or nebulised agents, they reduce sputum viscosity and aid expectoration, thereby theoretically shortening exacerbation length or frequency and improving symptoms ${ }^{17}$.

Although $\mathrm{CF}$ and previous studies have shown the potential benefit of hypertonic over $0.9 \%$ saline, more recently the evidence indicates equal efficacy in $\mathrm{NCFB}^{18}$. Further studies are required to show whether saline $(0.9 \%$ or hypertonic) is recommended in practice. Bilton et al. studied the effects of inhaled mannitol in a 12-month double-blinded $\mathrm{RCT}^{19}$. There was no statistically significant reduction in exacerbation rates; however, there was an improvement in time to first exacerbation and quality of life indicators ${ }^{19}$. The results are summarised in Table 2. Oral agents such as carbocisteine are commonly prescribed in the UK as part of bronchiectasis therapy; however, there are no RCTs to date. Dornase alfa therapy shows an increase in exacerbation rate in NCFB and is not recommended ${ }^{20}$.

Anti-inflammatory agents

This broad heading covers many drugs, including corticosteroids, non-steroidal anti-inflammatory drugs (NSAIDs), leukotriene receptor antagonists, and others. All have different mechanisms of action and vary as either long- or short-term therapy.

NSAIDs. There is some evidence to suggest the use of ibuprofen or other NSAIDs in patients with mild $\mathrm{CF}^{21}$. There are no studies that support their routine use in non-CF bronchiectasis. 
Table 2. Randomised controlled trial (RCT) on anti-inflammatory and muco-active agents.

\begin{tabular}{|c|c|c|c|c|}
\hline $\begin{array}{l}\text { Pharmacological } \\
\text { therapy }\end{array}$ & $\begin{array}{l}\text { Study and } \\
\text { authors }\end{array}$ & Study design and intervention & $\begin{array}{l}\text { Results } \\
\text { Lung function } \\
\text { Quality of life } \\
\text { Exacerbations } \\
\text { Others }\end{array}$ & $\begin{array}{l}\text { Adverse events (AEs) or } \\
\text { comments }\end{array}$ \\
\hline \multirow{4}{*}{$\begin{array}{l}\text { Anti-inflammatory } \\
\text { agents }\end{array}$} & \multirow{4}{*}{$\begin{array}{l}\text { Mandal et al. } .^{24} \\
\text { Atorvastatin } \\
\text { versus placebo }\end{array}$} & \multirow{4}{*}{$\begin{array}{l}\text { RCT } \\
\text { Placebo-controlled } \\
30 \text { subjects atorvastatin } 80 \mathrm{mg} O D \\
30 \text { subjects placebo OD } \\
6 \text { months }\end{array}$} & Spirometry: no change & \multirow{4}{*}{$\begin{array}{l}\text { Treatment group reported } \\
\text { more headaches and } \\
\text { gastrointestinal AEs }\end{array}$} \\
\hline & & & $\begin{array}{l}\text { Primary endpoint: improvement } \\
\text { in cough - LCQ (mean difference } \\
2.2,95 \% \mathrm{Cl} 0.5-3.9 ; p=0.01 \text { ) }\end{array}$ & \\
\hline & & & $\begin{array}{l}\text { Trend to reduced number of } \\
\text { exacerbations }\end{array}$ & \\
\hline & & & $\begin{array}{l}\text { Reduced CRP } \\
\text { Trend to improved incremental } \\
\text { walk test }\end{array}$ & \\
\hline \multirow[t]{4}{*}{$\begin{array}{l}\text { Muco-active } \\
\text { agents }\end{array}$} & \multirow{4}{*}{$\begin{array}{l}\text { Bilton et al. }{ }^{19} \\
\text { Inhaled mannitol }\end{array}$} & \multirow{4}{*}{$\begin{array}{l}233 \text { subjects mannitol } 400 \text { mg BD } \\
228 \text { control low-dose mannitol }\end{array}$} & No endpoint data on lung function & \multirow[t]{4}{*}{$\begin{array}{l}\text { AEs similar between } \\
\text { groups }\end{array}$} \\
\hline & & & $\begin{array}{l}\text { Secondary endpoint: quality of life } \\
\text { SGRQ improved in treatment arm }\end{array}$ & \\
\hline & & & $\begin{array}{l}\text { Primary endpoint: annual } \\
\text { exacerbation rates } \\
\text { No significant reduction } 1.69 \\
(95 \% \mathrm{Cl} 1.48-1.94) \text { and } 1.84 \\
(95 \% \mathrm{Cl} 1.61-2.10), p=0.32 \text {. }\end{array}$ & \\
\hline & & & $\begin{array}{l}\text { Secondary endpoint: time to } \\
\text { first exacerbation - improved in } \\
\text { mannitol group ( } 165 \text { days versus } \\
124 \text { days }[p=0.022] \text { ) } \\
\text { Duration of exacerbations: } \\
\text { no change }\end{array}$ & \\
\hline
\end{tabular}

6MWT, 6-minute walk test; BD, bis in die (twice daily); Cl, confidence interval; CRP, C-reactive protein; LCQ, Leicester Cough questionnaire; OD, omni die (every day); SGRQ, St George's respiratory questionnaire.

Leukotriene receptor antagonists. There are no studies to date for this subset of therapy specific to bronchiectasis.

Inhaled corticosteroids +/- long acting beta 2 agonists. The Cochrane review of the long-acting beta ${ }_{2}$ agonists (LABA) and inhaled corticosteroids (ICS) combination demonstrated a lack of quality evidence 22 . Only one RCT (2012) was highlighted in the 2014 review evaluating a bronchiectasis adult population without asthma who received inhaled budesonide and formoterol $(640 \mu \mathrm{g}$ and $18 \mu \mathrm{g})$ or high-dose budesonide $(1,600 \mu \mathrm{g})$. The authors found that there was an improvement in dyspnoea symptoms between the combination group and the ICS group ${ }^{23}$. Study size was small and it lacked statistically significant differences in outcomes ${ }^{23}$.

Predominant complications with long-term inhaled therapy are possible pneumonia risk, adrenal suppression, thin skin, and haemoptysis. This risk-benefit profile needs further investigation before management is accepted as routine in the bronchiectasis patient.

\section{Bronchodilator therapy}

Beta 2 adrenoreceptor agonists (short- and long-acting beta agonists). These agents have been illustrated in clinical trials for asthma and COPD; however, there have been none to date in bronchiectasis. Furthermore, there are no RCTs evaluating the use of inhaled anticholinergics. The role of bronchodilator therapy in bronchiectasis is unproven but often used in clinical practice with the breathless patient. If there is subjective improvement, it is sensible to continue such treatment.

\section{Other long-term therapies}

Mandal et al. reported the use of atorvastatin versus placebo with the primary endpoint of reducing cough ${ }^{24}$. Over a 6-month study period, the use of atorvastatin was shown to improve cough on quality of life questionnaire ${ }^{24}$; the results are discussed in Table 2.

Neutrophil elastase (NE) is a protease involved in inflammatory processes that has the ability to cause lung damage. It shows 
an increased activity in bronchiectasis. AZD9668 is an orally available NE inhibitor studied in a randomised, double-blinded, placebo-controlled phase II study by Stockley et al. ${ }^{25}$. A total of 16 patients were randomised to placebo and 22 to treatment for 28 days $^{25}$. There was no statistical significance in sputum neutrophil count or weight. Secondary endpoint of quality of life questionnaire showed a clinical difference suggestive of benefit, but the results did not meet significance ${ }^{25}$. Further studies on similar novel agents are encouraged in order to broaden our scope for long-term anti-inflammatory treatments.

\section{Macrolides}

The use of chronic macrolide therapy has been described for many respiratory conditions. The mechanism of action has been the point of research topics and includes anti-inflammatory, immunomodulatory, and antimicrobial actions. Their chronic use has been noted within the diffuse panbronchiolitis and CF populations ${ }^{26}$. This has spurred clinical trials in the bronchiectasis group.

Three major studies in 2012 and 2013 from Australia, New Zealand, and the Netherlands compared azithromycin daily, azithromycin three times weekly, and low-dose erythromycin and have led the way in establishing macrolide use in long-term bronchiectasis therapy ${ }^{27-29}$. Despite the publication date, all three studies (BLESS, BAT, and EMBRACE) have been included in this report because of their significance in current bronchiectasis management. The three trials reported their primary outcome as exacerbation frequency, and they have illustrated significant reduction in exacerbation rates ${ }^{27-29}$. There was some benefit in quality of life measures but a clinically insignificant improvement in lung function; Table 3 summarises the results.

Although long-term antibiotics are still not recommended on a routine basis, in a selected group based on frequent exacerbations (three or more per annum) or fewer exacerbations but increasing morbidity, this intervention should be considered. However, we must balance this with the possible emergence of antibiotic resistance and possible cardiovascular, audiologic, and gastrointestinal adverse events (AEs). A practical but prudent issue is the necessity to screen these patients for NTM infection prior to embarking upon long-term macrolide therapy, as this would have potential consequence on NTM management ${ }^{30}$.

The prospect of non-antimicrobial therapies and novel antiinflammatories exposes an exciting area for future phase II and III clinical trials.

Inhaled or aerosolised antibiotic or other therapies

With the burden of antimicrobial resistance increasingly real and a global political agenda for stewardship, the need for enhancing techniques and the delivery of antimicrobials responsibly with reduced adverse effects is paramount. Aerosolised and inhaled delivery within the lung has been of interest, as high concentrations of drug can be administered within the airways with reduced systemic side effects. The basis for inhaled antibiotics in bronchiectasis has not yet been established in clinical trials; however, recent work is exposing an exciting field. Currently, there are no approved inhaled antibiotics licensed for use by UK, European, or USA drug agencies for bronchiectasis.

Barker et al. studied the effects of inhaled aztreonam in bronchiectasis patients in two double-blinded, randomised, placebocontrolled trials ${ }^{31}$ (Table 3). Their primary endpoint of quality of life did not reach statistical significance, and they also reported more treatment-related $\mathrm{AEs}^{31}$.

Table 3 illustrates several RCTs analysing the safety and effect of inhaled or nebulised agents in long-term therapy. Haworth et al. studied the effectiveness of inhaled colistin for up to 6 months within 21 days of an exacerbation ${ }^{32}$. Although they did show a difference in the median time to first exacerbation, it did not reach statistical significance. However, improvements in secondary endpoints of bacterial density and quality of life did. This study also illustrated the importance of adherence, and, when taking more than $80 \%$ of therapy, it did improve the time to first exacerbation significantly ${ }^{32}$.

There are two phase III trials of inhaled ciprofloxacin, RESPIRE-1 and -2 , that have now been completed with the results awaited. They have two regimens comparing 28 days on and off for 1 year versus 14 days on and off for 1 year. A competitor study has utilised liposomes to allow slow release of ciprofloxacin and molecular stability in nebulisation and to improve delivery to macrophages ${ }^{33,34}$. Successful phase II studies of liposomal ciprofloxacin (pulmaquin) have shown a significant reduction in PA colony-forming units (CFUs) in sputum compared with placebo ${ }^{35}$. Subsequent to this, two identical international studies have completed enrolment to a phase III study (ORBIT-3 and -4$)^{36,37}$. The primary endpoint will be evaluation of time to first exacerbation, and secondary endpoints include quality of life measures ${ }^{37}$. Overall, the initial results are encouraging, prove tolerability, and promise a potential inhaled therapy for bronchiectasis (Table 3). The full reported results of ongoing phase III studies in inhaled ciprofloxacin and nebulised ciprofloxacin with liposomal technology are eagerly awaited.

\section{Summary}

There has been increased research activity in the field of bronchiectasis owing to its growing burden on healthcare systems secondary to reported increased prevalence. However, the quality of evidence in the field remains limited owing to the lack of RCTs. Long-term RCTs are greatly needed to further this field and improve patient outcome. 


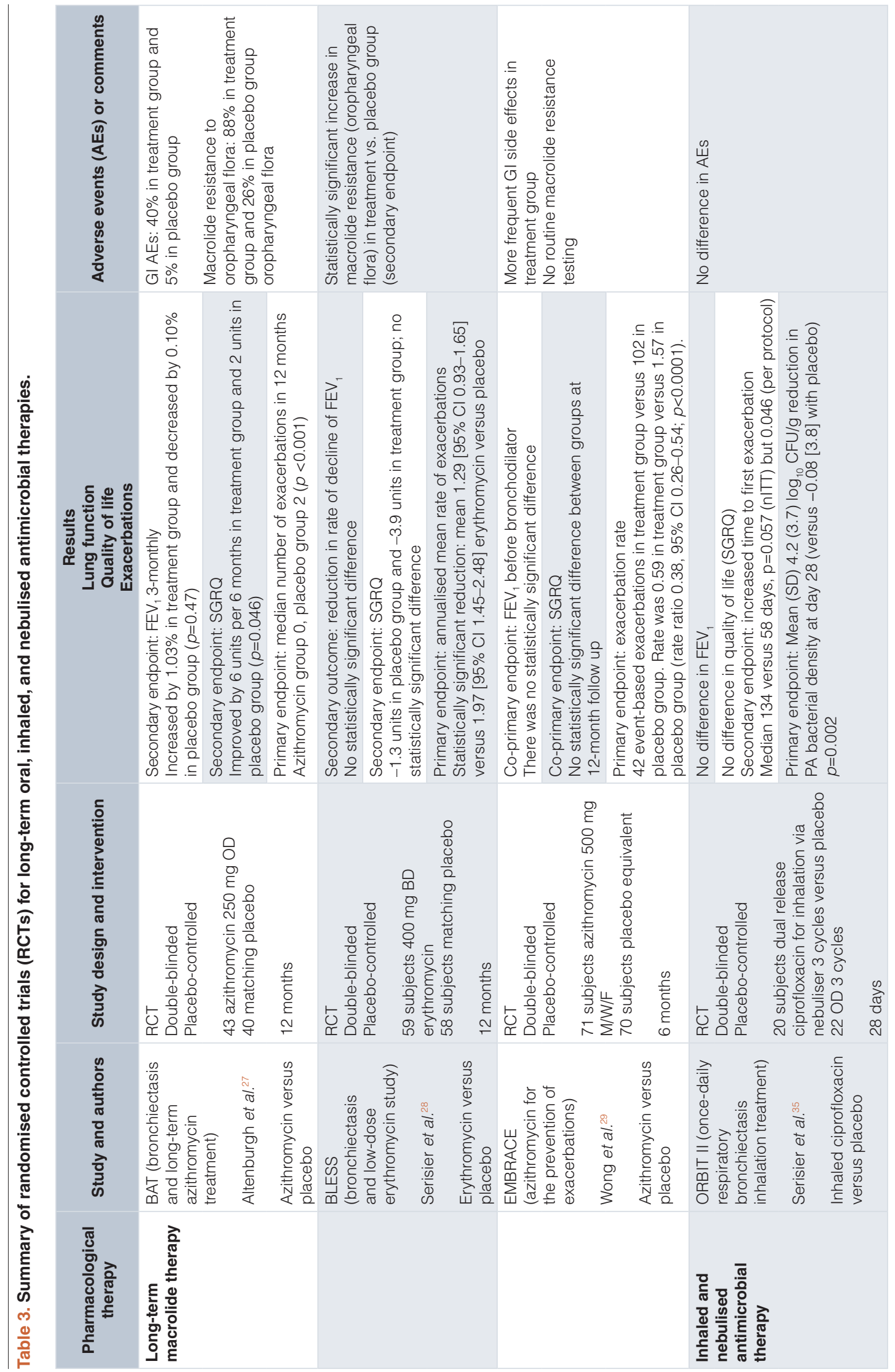




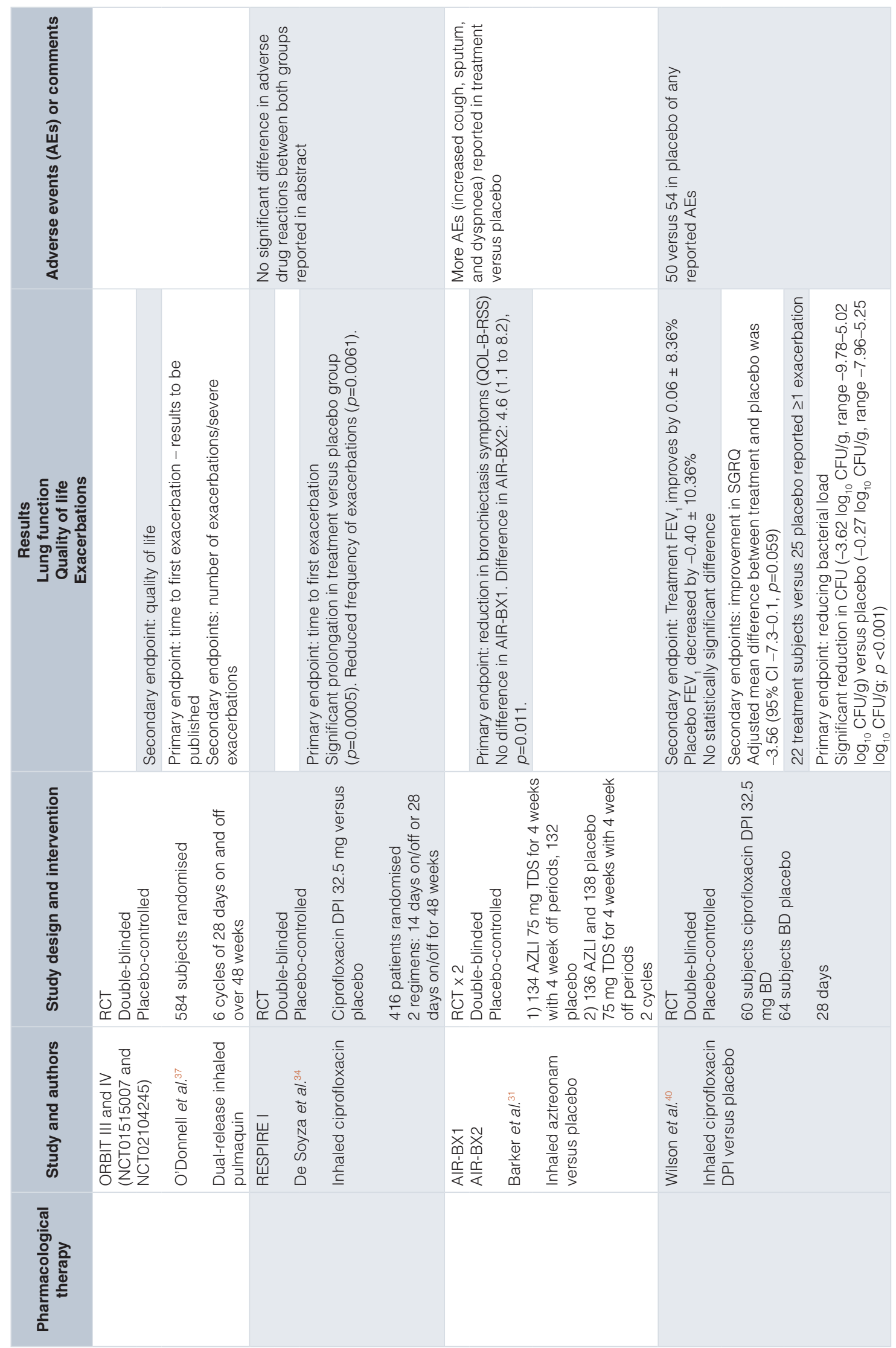




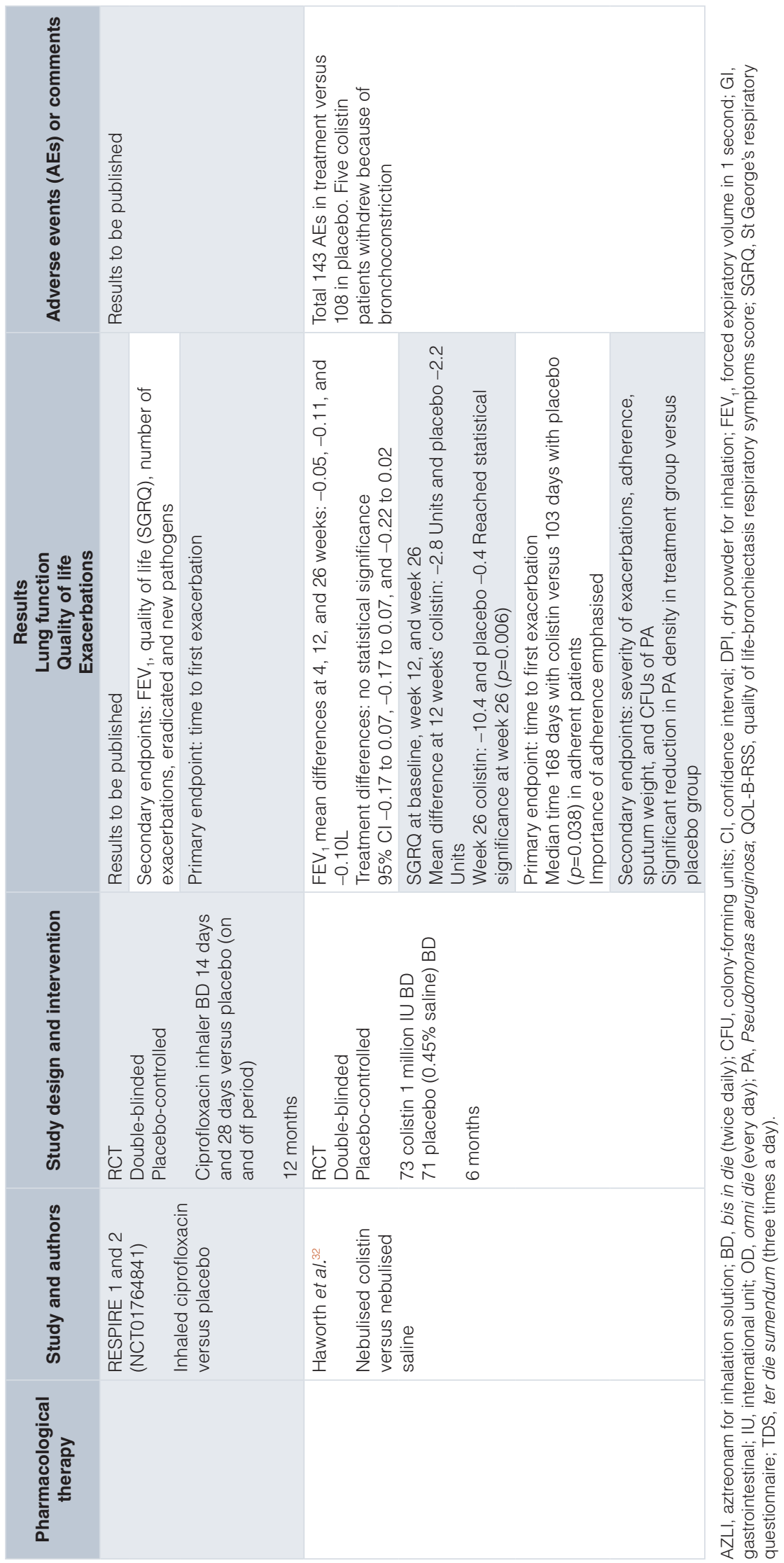


Competing interests

The authors declare that they have no competing interests.
Grant information

The author(s) declared that no grants were involved in supporting this work.
1. Chalmers JD, Aliberti S, Blasi F: Management of bronchiectasis in adults. Eur Respir J. 2015; 45(5): 1446-62.

PubMed Abstract | Publisher Full Text

2. Bilton D: Update on non-cystic fibrosis bronchiectasis. Curr Opin Pulm Med. 2008; 14(6): 595-9.

PubMed Abstract | Publisher Full Text

3. Pasteur MC, Bilton D, Hill AT: British Thoracic Society guideline for non-CF bronchiectasis. Thorax 2010; 65(7): 577.

PubMed Abstract | Publisher Full Text

4. $\mathrm{F}$ Quint JK, Millett ER, Joshi M, et al.: Changes in the incidence, prevalence and mortality of bronchiectasis in the UK from 2004 to 2013: a populationbased cohort study. Eur Respir J. 2016; 47(1): 186-93.

PubMed Abstract | Publisher Full Text | Free Full Text | F1000 Recommendation

5. Lonni S, Chalmers JD, Goeminne PC, et al.: Etiology of Non-Cystic Fibrosis Bronchiectasis in Adults and Its Correlation to Disease Severity. Ann Am Thorac Soc. 2015; 12(12): 1764-70.

PubMed Abstract | Publisher Full Text

6. Hill A, Bilton D, Brown J, et al:: British thoracic society quality standards for clinically significant bronchiectasis in adults July 2012. Br Thorac Soc Rep. 2012; 4: 1-16.

2012; 4: 1-16.

7. Guan WJ, Gao YH, Xu G, et al:: Aetiology of bronchiectasis in Guangzhou, southern China. Respirology. 2015; 20(5): 739-48.

PubMed Abstract | Publisher Full Text

8. Loebinger MR, Wells AU, Hansell DM, et al:: Mortality in bronchiectasis: a longterm study assessing the factors influencing survival. Eur Respir J. 2009; 34(4): 843-9.

PubMed Abstract | Publisher Full Text

9. Chalmers JD, Goeminne P, Aliberti S, et al:: The bronchiectasis severity index. An international derivation and validation study. Am J Respir Crit Care Med. 2014; 189(5): 576-85.

PubMed Abstract | Publisher Full Text | Free Full Text

10. F Martínez-García MÁ, de Gracia J, Vendrell Relat M, et al.: Multidimensional approach to non-cystic fibrosis bronchiectasis: the FACED score. Eur Respir J. 2014; 43(5): 1357-67.

PubMed Abstract | Publisher Full Text | F1000 Recommendation

11. Cole PJ: Inflammation: a two-edged sword--the model of bronchiectasis. Eur J Respir Dis Suppl. 1986; 147: 6-15. PubMed Abstract

12. Chang CC, Singleton RJ, Morris PS, et al.: Pneumococcal vaccines for children and adults with bronchiectasis. Cochrane Database Syst Rev. 2007; (2): CD006316.

PubMed Abstract | Publisher Full Text

13. McCool FD, Rosen MJ: Nonpharmacologic airway clearance therapies: ACCP evidence-based clinical practice guidelines. Chest. 2006; 129(1 Suppl): 250S-9. PubMed Abstract | Publisher Full Text

14. Burtin $\mathrm{C}$, Hebestreit $\mathrm{H}$ : Rehabilitation in patients with chronic respiratory disease other than chronic obstructive pulmonary disease: exercise and physical activity interventions in cystic fibrosis and non-cystic fibrosis bronchiectasis. Respiration. 2015; 89(3): 181-9. PubMed Abstract | Publisher Full Text

15. F Lee AL, Burge AT, Holland AE: Airway clearance techniques for bronchiectasis. Cochrane Database Syst Rev. 2015; (11): CD008351.

PubMed Abstract | Publisher Full Text | F1000 Recommendation

16. Finch $\mathrm{S}, \mathrm{McDonnell} \mathrm{MJ}$, Abo-Leyah $\mathrm{H}$, et al:: A Comprehensive Analysis of the Impact of Pseudomonas aeruginosa Colonization on Prognosis in Adult Bronchiectasis. Ann Am Thorac Soc. 2015; 12(11): 1602-11. PubMed Abstract | Publisher Full Text

17. F Wilkinson M, Sugumar K, Milan SJ, et al:: Mucolytics for bronchiectasis. Cochrane Database Syst Rev. 2014; (5): CD001289.

PubMed Abstract | Publisher Full Text | F1000 Recommendation

18. Nicolson $\mathrm{CH}$, Stirling RG, Borg BM, et al:: The long term effect of inhaled hypertonic saline $6 \%$ in non-cystic fibrosis bronchiectasis. Respir Med. 2012; 106(5): 661-7. PubMed Abstract | Publisher Full Text

19. F Bilton D, Tino G, Barker AF, et al.: Inhaled mannitol for non-cystic fibrosis bronchiectasis: a randomised, controlled trial. Thorax. 2014: 69(12): 1073-9. PubMed Abstract | Publisher Full Text | F1000 Recommendation
20. O'Donnell AE, Barker AF, llowite JS, et al.: Treatment of idiopathic bronchiectasis with aerosolized recombinant human DNase I. rhDNase Study Group. Chest. 1998; 113(5): 1329-34.

PubMed Abstract | Publisher Full Text

21. Pizzutto SJ, Upham JW, Yerkovich ST, et al:: Inhaled non-steroid antiinflammatories for children and adults with bronchiectasis. Cochrane Database Syst Rev. 2016; (1): CD007525.

PubMed Abstract | Publisher Full Text

22. F Goyal V, Chang AB: Combination inhaled corticosteroids and long-acting eta -agonists for children and adults with bronchiectasis. Cochrane Database Syst Rev. 2014; (6): CD010327.

PubMed Abstract | Publisher Full Text | F1000 Recommendation

23. Martínez-García MÁ, Soler-Cataluña JJ, Catalán-Serra P, et al.: Clinical efficacy and safety of budesonide-formoterol in non-cystic fibrosis bronchiectasis. Chest. 2012; 141(2): 461-8.

PubMed Abstract | Publisher Full Text

24. Mandal P, Chalmers JD, Graham C, et al.: Atorvastatin as a stable treatment in bronchiectasis: a randomised controlled trial. Lancet Respir Med. 2014; 2(6) 455-63.

PubMed Abstract | Publisher Full Text

25. Stockley R, De Soyza A, Gunawardena K, et al.: Phase II study of a neutrophil elastase inhibitor (AZD9668) in patients with bronchiectasis. Respir Med. 2013; 107(4): 524-33.

PubMed Abstract | Publisher Full Text

26. Gao YH, Guan WJ, Xu G, et al.: Macrolide therapy in adults and children with non-cystic fibrosis bronchiectasis: a systematic review and meta-analysis. PLoS One. 2014; 9(3): e90047.

PubMed Abstract | Publisher Full Text | Free Full Text

27. F Altenburg J, de Graaff CS, Stienstra Y, et al.: Effect of azithromycin maintenance treatment on infectious exacerbations among patients with non-cystic fibrosis bronchiectasis: the BAT randomized controlled trial. JAMA. 2013. 309(12): 1251-9.

PubMed Abstract | Publisher Full Text | F1000 Recommendation

28. F Serisier DJ, Martin ML, McGuckin MA, et al:: Effect of long-term, low-dose erythromycin on pulmonary exacerbations among patients with non-cystic fibrosis bronchiectasis: the BLESS randomized controlled trial. JAMA. 2013; 309(12): 1260-7.

PubMed Abstract | Publisher Full Text | F1000 Recommendation

29. F Wong C, Jayaram L, Karalus N, et al:: Azithromycin for prevention of exacerbations in non-cystic fibrosis bronchiectasis (EMBRACE): a randomised, double-blind, placebo-controlled trial. Lancet. 2012; 380(9842): $660-7$.

PubMed Abstract | Publisher Full Text | F1000 Recommendation

30. Spreading US Macrolide Resistance. JAMA. 2015; 314(12): 1218. Publisher Full Text

31. $\mathrm{F}$ Barker AF, O'Donnell AE, Flume $\mathrm{P}$, et al:: Aztreonam for inhalation solution in patients with non-cystic fibrosis bronchiectasis (AIR-BX1 and AIR-BX2): two randomised double-blind, placebo-controlled phase 3 trials. Lancet Respir Med. 2014; 2(9): 738-49.

2014; 2(9): 738-49.
PubIMed Abstract | Publisher Full Text | F1000 Recommendation

32. $\mathrm{F}$ Haworth CS, Foweraker JE, Wilkinson $\mathrm{P}$, et al:: Inhaled colistin in patients with bronchiectasis and chronic Pseudomonas aeruginosa infection. $\mathrm{Am} \mathrm{J}$ Respir Crit Care Med. 2014; 189(8): 975-82.

PubMed Abstract | Publisher Full Text | Free Full Text | F1000 Recommendation

33. Cipolla D, Blanchard J, Gonda I: Development of Liposomal Ciprofloxacin to Treat Lung Infections. Pharmaceutics. 2016; 8(1): pii: E6. PubMed Abstract | Publisher Full Text | Free Full Text

34. De Soyza A, Aksamit T, Bandel TJ, et al.: LATE-BREAKING ABSTRACT: RESPIRE 1: Ciprofloxacin DPI $32.5 \mathrm{mg}$ bd administered 14 day on/off or 28 day on/off vs. placebo for 48 weeks in subjects with non-cystic fibrosis bronchiectasis (NCFB). Eur Respir J. 2016. 48(suppl 60): OA272. Publisher Full Text

35. F Serisier DJ, Bilton D, De Soyza A, et al:: Inhaled, dual release liposomal ciprofloxacin in non-cystic fibrosis bronchiectasis (ORBIT-2): a randomised, double-blind, placebo-controlled trial. Thorax. 2013; 68(9): $812-7$.

PubMed Abstract | Publisher Full Text | Free Full Text | F1000 Recommendation 
36. Bilton D, Serisier D, Wanner A, et al: Orbit-3 And Orbit-4: Design Of A Phase 3 Program To Investigate Safety And Efficacy Of Pulmaquin® In NonCystic Fibrosis Bronchiectasis (ncfbe) Patients Chronically Colonized With Pseudomonas Aeruginosa (pa). Am J Respir Crit Care Med. 193: p.2016.

37. O'Donnell AE, Bilton D, Serisier D, et al.: ORBIT-3 And ORBIT-4: Design Of A Phase 3 Program To Investigate Safety And Efficacy Of Pulmaquin® In NonCystic Fibrosis Bronchiectasis (NCFBE) Patients Chronically Colonized With Pseudomonas Aeruginosa (PA). In A51. BRONCHIECTASIS: CLINICAL AND EPIDEMIOLOGIC STUDIES. American Thoracic Society. 2016; 193: A1775-A1775.

Reference Source

38. Lee AL, Hill CJ, Cecins N, et al:: The short and long term effects of exercise training in non-cystic fibrosis bronchiectasis--a randomised controlled trial. Respir Res. 2014; 15(1): 44

PubMed Abstract | Publisher Full Text | Free Full Text

39. Nicolini A, Cardini F, Landucci N, et al.: Effectiveness of treatment with highfrequency chest wall oscillation in patients with bronchiectasis. BMC Pulm Med. 2013; 13: 21

PubMed Abstract | Publisher Full Text | Free Full Text

40. F Wilson R, Welte T, Polverino E, et al.: Ciprofloxacin dry powder for inhalation in non-cystic fibrosis bronchiectasis: a phase II randomised study. Eur Respir J. 2013; 41(5): 1107-15.

PubMed Abstract | Publisher Full Text | Free Full Text | F1000 Recommendation 


\section{Open Peer Review}

\section{Current Peer Review Status:}

\section{Editorial Note on the Review Process}

Faculty Reviews are review articles written by the prestigious Members of Faculty Opinions. The articles are commissioned and peer reviewed before publication to ensure that the final, published version is comprehensive and accessible. The reviewers who approved the final version are listed with their names and affiliations.

\section{The reviewers who approved this article are:}

\section{Version 1}

\section{Diana Bilton}

Department of Respiratory Medicine, Royal Brompton Hospital, London, UK

\section{Michael Loebinger}

Royal Brompton \& Harefield Hospital Foundation Trust and Imperial College London, London, UK Competing Interests: No competing interests were disclosed.

\section{Miguel Ángel Martinez-García}

Hospital Universitario y Politécnico La Fe, Valencia, Valencia, Spain

Competing Interests: No competing interests were disclosed.

The benefits of publishing with F1000Research:

- Your article is published within days, with no editorial bias

- You can publish traditional articles, null/negative results, case reports, data notes and more

- The peer review process is transparent and collaborative

- Your article is indexed in PubMed after passing peer review

- Dedicated customer support at every stage

For pre-submission enquiries, contact research@f1000.com

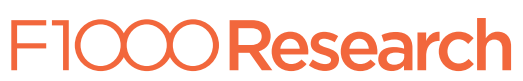

